https://helda.helsinki.fi

\title{
International travel to obtain medical treatment for primary retinoblastoma : A global cohort study
}

\section{Bowman, Richard J. C.}

2021-04-15

Bowman , R J C , Foster , A , Stacey , A , Keren-Froim , N , Bascaran , C , Kivelä , T T , Munier , F \& Fabian , I D 2021 , ' International travel to obtain medical treatment for primary retinoblastoma : A global cohort study ' , International Journal of Cancer , vol. 148 , no. 8 , pp. 1858-1866 . https://doi.org/10.1002/ijc.33350

http://hdl.handle.net/10138/339491

https://doi.org/10.1002/ijc.33350

acceptedVersion

Downloaded from Helda, University of Helsinki institutional repository.

This is an electronic reprint of the original article.

This reprint may differ from the original in pagination and typographic detail.

Please cite the original version. 
International travel to obtain medical treatment for primary retinoblastoma: a global cohort study

RJC Bowman ${ }^{1}$

A Foster ${ }^{1}$

A Stacey ${ }^{2}$

N Keren-Froim ${ }^{3}$

C Bascaran ${ }^{1}$

T T Kivelä ${ }^{4}$

F Munier ${ }^{5}$

ID Fabian ${ }^{1,6}$

Affiliations:

1. International Centre for Eye Health, London School of Hygiene and Tropical Medicine

2. Department of Ophthalmology, University of Washington, Seattle, Washington, USA

3. Sackler Faculty of Medicine, Tel-Aviv University, Tel-Aviv, Israel

4. Ocular Oncology Service, Department of Ophthalmology, University of Helsinki and Helsinki University Hospital, Helsinki, Finland,

5. Jules-Gonin Eye Hospital, Fondation Asile de Aveugles, University of Lausanne,

Lausanne, Switzerland,

6. Goldschleger Eye Institute, Sheba Medical Center, Tel Hashomer, Tel-Aviv University,

Tel-Aviv, Israel

Word count: 1789

Correspondence to:

Richard Bowman

London School of Hygiene and Tropical Medicine, Keppel Street, London WC1E 7HT, UK

Tel: +44(0) 2079588346

Email: richardbowman493@gmail.com

Key words: tourism, international, retinoblastoma, travel

This article has been accepted for publication and undergone full peer review but has not been through the copyediting, typesetting, pagination and proofreading process which may lead to differences between this version and the Version of Record. Please cite this article as doi: $10.1002 / \mathrm{ijc} .33350$ 


\title{
Novelty and Impact
}

International medical travel has received little attention in oncology, and retinoblastoma. We report that $5 \%$ of a comprehensive global cohort of patients with newly diagnosed retinoblastoma were treated abroad in 2017. This may help save the eye and vision but also may delay treatment, a risk exacerbated during pandemics and other crises when international borders are shut down. These findings should promote co-ordinated global provision of specialist eye cancer centres and emergency travel arrangements.

\author{
Abbreviations \\ GATS - World Trade Organization's General Agreement on Trade in Services \\ $\mathrm{Rb}$ - retinoblastoma \\ TNM classification - (American Joint Committee on Cancer Tumor, Node, Metastasis category) \\ WHO - World Health Organization
}




\begin{abstract}
Early diagnosis and treatment of retinoblastoma ( $\mathrm{Rb})$, the most common intraocular malignancy, can save both the child's life and vision. However, access to services and hence chances for survival and preserving the eye and its vision vary widely across the globe. Some families have to, or make a choice to, leave their home country to seek planned medical treatment abroad.

We aimed to investigate how frequently this cross border travel occurs and the factors associated with it.

A total of $278 \mathrm{Rb}$ centers in 153 countries were recruited to participate in a global cross-sectional analysis of newly diagnosed $\mathrm{Rb}$ patients in 2017.

Number and proportions of children who travelled from their home country for treatment were analysed by country, continent, socio-economic stratum, and clinical and demographic features. The cohort included 4,351 new patients of whom $223(5.1 \%, 95 \% \mathrm{Cl} 4.5-5.8)$ were taken across country borders for planned medical treatment. Independently significant predictors of travelling across borders included: being from a country with a smaller population, being from a country classified as low socioeconomic status, having bilateral $\mathrm{Rb}$, and having intra-ocular disease without extra-ocular spread.

The factors that determine international travel for retinoblastoma treatment are complex and deserve further investigation. We may need to rethink the way services are delivered in the light of the threat of severe curtailment of international travel from pandemics like COVID-19.
\end{abstract}




\section{Introduction}

Retinoblastoma $(\mathrm{Rb})$ is a rare and potentially deadly childhood cancer. Its incidence (except for familial cases) is thought to be constant across the globe, ranging from 1:16,000-18,000 live births (1). In most countries, because of the need for specialist care, only a single or a few specialized Rb centers exist. In Europe, for example, there is a single center in France in Paris, two in the UK, both in England (London and Birmingham), and three in Russia, all in Moscow. Such a policy of centralized tertiary centers likely improve outcomes for those that reach them in time but may also impede access and impose high travel burdens on patients, which can lead to poorer quality of life, more advanced disease at diagnosis, later treatment, and worse prognosis $(2,3)$.

We recently recruited a global cohort of more than 4,000 newly diagnosed patients with $\mathrm{Rb}$ from over 150 countries and reported presentation patterns by national-income level. The dataset has been published on an online repository (4). Establishment of this cohort has led to increased interest in global networking, expertise sharing, and planning for a rare disease such as $\mathrm{Rb}$. In particular, a desire to work together has emerged to aid access to specialist treatment centres for children from low income countries, currently a major problem as discussed in our report (5).

We previously described gross disparity in the stage of disease at presentation at specialist centres by socioeconomic status of the country of origin (5). Likely reasons include lack of awareness of the urgency and poor access to specialist services because of the expense and travel distance. Because tumour stage at the time of presentation to the specialist centre is likely to have a profound effect on visual prognosis and survival (6), it is important to investigate these accessibility issues in detail. In some cases travel to a foreign country is necessary or preferred by families.

Medical travel is the second mode of trade in health services as defined in the World Trade Organization's General Agreement on Trade in Services (GATS) (7). It is a growing and still poorly understood phenomenon. As part of our initiative to investigate and improve access to $\mathrm{Rb}$ treatment, we have investigated the subgroup of families who travel to a different country for planned primary medical treatment. We aimed to investigate for the first time the frequency of this phenomenon and the factors which influence it.

\section{Methods}

We collected data as an international, multicenter, one-year cross-sectional cohort, as described in detail previously, of 4351 children, median age 30.5 months, interquartile range $14-86$ months, $45 \%$ female, $85 \%$ from low and middle income countries (5). Rb treatment centers from all continents reported all new patients with Rb who presented between 1 January 2017 and 31 December 2017. The recruitment steps are summarized in figure 1 . Country populations and classification by national-income level was obtained from the World Population Prospects 2017 (8) of the United Nations. 
The study was approved by the London School of Hygiene \& Tropical Medicine Institutional Review Board (reference no. 14574), who granted a waiver of informed consent. Participating centres applied to and received ethics clearance in their countries according to local institutional guidelines.

The number and percentage (with 95\% confidence interval) of children taken across national borders for planned primary $\mathrm{Rb}$ treatment were calculated for the whole sample, and then by continent and socioeconomic category of the country of origin. Mean ages of children who were treated abroad rather than in their country of origin were compared. Percentages of children travelling across country borders for treatment were then compared by 4 other binary variables which we judged to be possible effectors: sex, family history of Rb, bilaterality of Rb, and extraocular spread of Rb. Patient and country related factors found to be associated with travelling across borders were entered into a multiple logistic regression model to investigate their independence (SPSS). Cases where one or more of these data were missing were eliminated case by case for the univariate analyses. Only cases with a complete set of data for significant predictor variables were included in the regression model.

\section{Results}

The overall number out of the 4,351 children who were taken across country borders for planned primary medical treatment for $\mathrm{Rb}$ was $223(5.1 \%, 95 \% \mathrm{Cl} 4.5-5.8)$. The number and percentage of children being taken across borders divided by possible geographic, socioeconomic, and clinical predictors are shown in table 1. The phenomenon was seen most commonly in Europe (9.6\%), followed by Africa, Asia and then Latin America (1.9\%). Cross border travel was not seen in North America or Oceania.

The numbers and percentages of children travelling across borders by country of origin are shown in table 2 together with the socioeconomic status of each country and number of specialist Rb centers in each country from where at least one child travelled. Fifty-three of the 223 children (24\%) who travelled abroad came from countries with no specialist $\mathrm{Rb}$ center.

Multiple logistic regression analysis analysis showed that independently significant predictors for children to travel across borders for planned primary treatment of Rb were: being from a smaller country (population less than the median of $97.5 \mathrm{M})(p<0.0005)$, being from a country classified as low socioeconomic status $(P<0.001)$, having bilateral $\mathrm{Rb}(\mathrm{p}<0.0005)$ and having intra-ocular $\mathrm{Rb}$ without extra-ocular spread $(\mathrm{P}<0.015)$. These remained independent predictors for travel whether or not the 53 children from countries without a center were included. (table 3 )

Figures 2-4 show the patterns of cross border travel by continent, socioeconomic status, and world geography. Europe where cross border travel was seen most commonly is shown in greater detail in figure 5. 


\section{Discussion}

A number of complex factors are thought to influence decisions to travel for medical treatment. A World Health Organization (WHO 2006) resolution on international trade and health (WHA 59.26) urged member states to understand the implications of international trade and trade agreements for health and to address the issues through policies and regulations (9). The increasing acceptance of health care internationalism is evident in Europe, where greater patient mobility led to an EU Directive on cross-border health care (10). Although international travel within Europe was common in our cohort, the recent corona virus disease-19 (COVID-19) crisis has imposed almost a complete halt to obtaining planned medical care abroad and, indeed, sometimes even in their home country, and has resulted in some children having had to have both eyes removed in their home country instead of receiving chemotherapy at a specialist center abroad (unpublished data, IDF). This illustrates the importance of studying the patterns of this type of cross border travel.

There are few data reporting numbers of 'medical tourists' in general (11) and for cancer or for conditions of childhood. Recent work on the ethics of commercial medical tourism has noted that oncology generated $£ 378$ million in London in 2017 with most patients coming from the Middle East but also from Europe, China and the USA (12). The United Arab Emirates were estimated to have spent US\$163 in 2013 on international cancer care (13) Patients coming from less developed countries are often sponsored by the government of their country of origin despite the fact that in some cases local treatment is available (14). Review of the literature on this subject reveals more financial data than epidemiological or clinical since it is a large industry. The authors highlight ethical, medical and communication issues that arise from this practice $(13,14)$. In our experience of $\mathrm{Rb}$, familes are often seeking treatment that is not available to them, at any cost, in their home country; or the government is sending them abroad because they have too few patients to justify a specialist centre. They are desperate to save the eye, and to avoid enucleation, and collect money from any source to make this happen.

We used our large global cohort data to systematically investigate some of the factors that might be associated with the decision to travel to another country for planned primary Rb treatment, and our data shows that geographic, socioeconomic and clinical factors likely all play a part.

We found differences in the frequency of cross border travel for primary treatment of $\mathrm{Rb}$ in the five continents of the world. Children from North America and Oceania were not shown to travel abroad although it is well known that in the United States may families may travel long distances to the specialized center of their choice. Increasing proportions of travelling abroad were seen from Latin America and the Caribbean to Asia, Africa and, finally, Europe which had the highest percentage of cross border travel. This resulted largely from the fact that of the 20 European countries, 6 smaller ones did not have a specialist $\mathrm{Rb}$ center, necessitating planned and usually government-organized travel across borders. The rational need for and the number of $\mathrm{Rb}$ centers within an individual 
country are related to the annual number of new patients. Enough centers with an appropriate geographic distribution are needed to conveniently serve all patients within a country, but the ideal number is limited by the need for each expert center to gain enough experience of managing $\mathrm{Rb}$ (15). Rare disease networks can potentially help achieve a compromise by pooling resources across countries and centres for rare diseases like $\mathrm{Rb}$. Incidence trends can be detected earlier and risk factors appropriately investigated. Survival might potentially be improved by early diagnosis, new treatments, and improved case management (16). Almost all the European children who crossed borders (48/50) travelled to another European country. The ease and relatively low cost of travel within much of Europe may in part explain why it was most common and practical there., In addition, European Union (EU) law specifically gives the right to obtain treatment from another EU country (including Switzerland) if a treatment is not available in the home country. The Rarecare study in Europe showed a higher level of centralization of treatment of Rb compared to other tumours though there was intercountry variation (16). However the multiple logistic regression analysis showed that smaller population size was an overriding reason for high rates of travel in Europe (since when it was included in the model, Europe ceased to be an independent factor) . Also in other continents, the large majority of cross border travel occurred within the continent, with additional small numbers of people from Africa travelling to Europe or Asia, and small numbers of people from Asia travelling to Europe or North America.

The effect of socioeconomic status was not as clear as the geographic differences, except for the lowest band of countries from which children were more likely to travel. This is a separate factor from the geographic continent because none of the European countries belong to this lowest socioeconomic band. Figure 3 shows that, although most of this movement across socioeconomic gradient was from poorer to richer countries, 25 patients from outside the lowest socioeconomic grouping travelled to poorer countries. These 25 were mainly in North Africa and the Middle East, Amman in Jordan and Tunis being the most frequent treatment centres.

We have previously reported that, in European countries, travel distance from home to a $\mathrm{Rb}$ center is not a barrier to early diagnosis (17). European patients travelled on average more than $400 \mathrm{~km}$ and yet $>60 \%$ presented with a tumor confined to the globe (American Joint Committee on Cancer Tumor, Node, Metastasis category cT2) (18), whereas African patients travelled on average of less than $200 \mathrm{~km}$, yet $>80 \%$ presented with advanced disease, some with extraocular tumour spread (cT3 or worse), suggesting that factors other than geographic distance to retinoblastoma center play a role in late disease diagnosis. This is reinforced by the findings of this study, which show that the patients who managed to cross borders had less advanced disease, in that they were less likely to have spread beyond the eye.

Clinical predictors of travelling for primary treatment of $\mathrm{Rb}$ were bilateral tumor and tumor confined to the eye. Patients with both eyes affected might be more likely to be taken abroad for treatment either because of the feeling that bilateral disease is more serious or because it is always accompanied by risk of blindness. However extraocular disease might also have been expected to be 
seen as more serious disease, but fewer children with extraocular spread were taken abroad. This may be because conventional chemotherapy and enucleation to manage this stage of the disease are more widespread than are intra-arterial chemotherapy and brachytherapy to save an eye with advanced or otherwise vision-threatening intraocular disease, or it may be that families with the resources to travel out of their country seek care and are diagnosed earlier and before extra-ocular spread. In Lausanne, Switzerland, for instance, 9 of the 18 patients originated from countries without an Rb specialist, 5 from a country where intra-arterial chemotherapy is not available (which may be the only way of avoiding removal of the eye) and 4 chose to be treated in Lausanne for other reasons (FM personal communication).

Limitations of our data have previously been reported (4) and include the convenience sampling technique, predominantly retrospective reporting, and socioeconomic stratification by country rather than individual families. This stratification of possible factors associated with international travel by country as opposed to by individual family factors limits the power of this study to investigate the complex reasons behind the decision to travel. In addition there were potential factors which we did not directly investigate eg national guidelines, population size, distance to travel. In addition, this study is focused on first line treatment tourism which is capturing only a part of the medical tourism of retinoblastoma. During the same year (2017) Lausanne received 33 new non-Swiss patients coming for second or third opinion, having already received some treatment elsewhere, whereas only a separate 18 treatment naïve patients were reported in this cohort (FM personal communication). In addition the sample is incomplete. Figure 1 shows that 20 invited centers did not report patients. This included 6 who had no cases that year, 6 who had cases but did not report (including one high volume center in North America and one in Africa) and 8 for whom we have no information. Nevertheless, it is the largest and most globally comprehensive cohort of retinoblastoma patients so far reported.

In summary, we have shown that around $5 \%$ of the world population of retinoblastoma patients travel across national borders for diagnosis and primary treatment and that the factors that influence this are complex and include geography, population size, ease of international travel, national government guidelines, availability of domestic specialist services, socioeconomic status of the home country, and the clinical features of the disease. The combination of these factors varies from continent to continent. We recommend further investigation of this phenomenon: better understanding of the patterns of cross border travel and the factors influencing them will help us, as a global retinoblastoma community, prioritize which countries require specialist centers and regions of the world where cross border travel for medical reasons, especially for rare and lethal disease, need to be made politically and economically easier. Furthermore, the community may need to rethink the way services are delivered in the light of the threat of severe curtailment of international travel from pandemics like COVID-19.

Acknowledgements: This study was funded by the Queen Elizabeth Diamond Jubilee Trust. 
Conflict of Interests: the authors have none to declare.

Data availability statement: The dataset has been published on an online repository (4) [https://zenodo.org/record/3727687\#.Xny7blgzblU].

Ethical statement: The study was approved by the London School of Hygiene \& Tropical Medicine Institutional Review Board (reference no. 14574), who granted a waiver of informed consent.

Participating centers applied to and received ethics clearance in their countries according to local institutional guidelines. 
References

1. Kivelä T. The epidemiological challenge of the most frequent eye cancer: retinoblastoma, an issue of birth and death. Br J Ophthalmol. 2009 Sep;93(9):1129-31.

2. Ambroggi M, Biasini C, Del Giovane C, Fornari F, Cavanna L.Distance as a Barrier to Cancer Diagnosis and Treatment: Review of the Literature. Oncologist. 2015 Dec;20(12):1378-85.

3. Gatta G, van der Zwan JM, Casali PG, Siesling S, Dei Tos AP, Kunkler I, Otter R, Licitra L, Mallone S, Tavilla A, Trama A, Capocaccia R; RARECARE working group. Rare cancers are not so rare: the rare cancer burden in Europe. Eur J Cancer. 2011 Nov;47(17):2493-511.

4. Fabian ID, Stacey A, Foster A, Kivelä TT, Munier FL, Cassoux N, \& Bowman RJC. (2020). Global Retinoblastoma Presentation 2017 data, on behalf of the Global Retinoblastoma Study Group [Data set]. Zenodo. http://doi.org/10.5281/zenodo.3727687

5. Global Retinoblastoma Study Group. Global Retinoblastoma Presentation and Analysis by National Income Level. JAMA Oncol. 2020 Feb 27.

6. Chawla B, Hasan F, Azad R, Seth R, Upadhyay AD, Pathy S, Pandey RM. Clinical presentation and survival of retinoblastoma in Indian children. Br J Ophthalmol. 2016

7. https://www.wto.org/english/tratop e/serv e/health social e/health social e.htm Feb;100(2):172-8.

8. United Nations, Department of Economic and Social Affairs PD (2017). World Population Prospects: The 2017 Revision, Volume I: Comprehensive Tables (ST/ESA/SER.A/399).

9. (WHO) Who . Trade and health. 2016.

10. Legido-Quigley H, Passarani I, Knai C, et al. Cross-border healthcare in the European Union: clarifying patients' rights. BMJ 2011; 342:d296.

11. What do we know about medical tourism? A review of the literature with discussion of its implications for the UK National Health Service as an example of a public health care system. Hanefeld J, Smith R, Horsfall D, Lunt N. J Travel Med. 2014 Nov-Dec;21(6):410-7. doi: 10.1111/jtm.12147. Epub 2014 Aug 25.

12. Burki TK. UK health tourism for private cancer care. Lancet Oncol. 2019 Mar;20(3):334.

13. Benedetti DJ, Golshan M, Kesselheim JC. Going the Distance: Ethical Issues Arising When Patients Seek Cancer Care From International Settings. J Glob Oncol. 2018 Sep;4:1-4.

14. Al-Shamsi HO, Al-Hajeili M, Alrawi S. Chasing the Cure Around the Globe: Medical Tourism for Cancer Care From Developing Countries. J Glob Oncol. 2018 Sep;4:1-3.

15. Blay JY, Honoré C, Stoeckle E, et al. Surgery in reference centers improves survival of sarcoma patients: a nationwide study. Ann Oncol 2019; 30: 1143-53.

16. Lancet Oncol 2017 Aug;18(8):1022-1039. doi: 10.1016/S1470-2045(17)30445-X. Epub 2017 Jul 4. Burden and centralised treatment in Europe of rare tumours: results of RARECAREneta population-based study Gemma Gatta 1, Riccardo Capocaccia 2, Laura Botta 2, et al. RARECAREnet working group

17. Fabian ID, Stacey, AW, Foster A, et al. Br J Ophthalmol Epub ahead of print:doi:10.1136/bjophthalmol-2020-316613

18. Mallipatna AC, Gallie BL, Chévez-Barrios $P$ et al. Retinoblastoma. In: Amin MB, Edge SB, Greene FL, et Al., Eds. AJCC Cancer Staging Manual. 8th Ed. New York: Springer; 2017. 


\section{Figure legends.}

Figure 1 - Summary of recruitment to the 2017 Global retinoblastoma cohort

Figure 2 - Intercontinental travel for planned primary retinoblastoma treatment

Figure 3 - Travel for planned primary retinoblastoma treatment across socio-economic strata

Figure 4-Intercountry travel for planned primary retinoblastoma treatment illustrated on a world map

Figure 5 - Intercountry travel for planned primary retinoblastoma treatment within Europe 
Table 1 Characteristics of 223 Retinoblastoma patients who travelled outside their country of residency for treatment and 4,128 who were treated in their country of residency, 2017

\begin{tabular}{|c|c|c|c|c|}
\hline & \multicolumn{2}{|c|}{$\begin{array}{l}\text { Sub-group \#1: number (\%) of } \\
\text { patients that travelled across } \\
\text { borders }\end{array}$} & \multirow{2}{*}{$\begin{array}{l}\text { Sub-group \#2: number of } \\
\text { patients diagnosed and } \\
\text { treated within their } \\
\text { country of residence } \\
\text { Number }\end{array}$} & \multirow{2}{*}{$\begin{array}{l}\text { Significance } \\
\text { (for } 2 \text { way } \\
\text { comparisons) } \\
\end{array}$} \\
\hline & Number & $\%(95 \% \mathrm{Cl})$ & & \\
\hline Total & 223 & $\begin{array}{c}5.1 \% \\
(4.5-5.8)\end{array}$ & 4128 & \\
\hline \multicolumn{4}{|c|}{ Continent (by increasing rate of cross border travel) } & \\
\hline Oceania & None & & 17 & \\
\hline North America & None & & 200 & \\
\hline LAC & 6 & $\begin{array}{c}1.9 \% \\
(0.4-3.5)\end{array}$ & 306 & \\
\hline Asia & 99 & $\begin{array}{c}4.3 \% \\
(3.5-5.2)\end{array}$ & 2177 & \\
\hline Africa & 68 & $\begin{array}{c}6.6 \% \\
(5.1-8.2)\end{array}$ & 956 & \\
\hline Europe & 50 & $\begin{array}{c}9.6 \% \\
(7.0-12.1))\end{array}$ & 419 & \\
\hline \multicolumn{4}{|c|}{ National income level (by increasing rate of cross border travel) } & \\
\hline Lower-middle & 77 & $\begin{array}{c}4.0 \% \\
(3.1-4.8) \\
\end{array}$ & 1863 & \\
\hline High & 28 & $\begin{array}{c}4.2 \% \\
(2.7-5.7)\end{array}$ & 638 & \\
\hline Upper-middle & 63 & $\begin{array}{c}5.2 \% \\
(3.9-6.4)\end{array}$ & 1144 & \\
\hline Low & 55 & $\begin{array}{c}10.3 \% \\
(7.7-12.9) \\
\end{array}$ & 478 & \\
\hline \multicolumn{4}{|l|}{ Sex } & $\mathrm{P}=0.33$ \\
\hline Male & 129( & $\begin{array}{c}5.4 \% \\
(4.5-6.3)\end{array}$ & 2246 & \\
\hline Female & 94 & $\begin{array}{c}4.8 \% \\
(3.8-5.7)\end{array}$ & 1882 & \\
\hline \multicolumn{4}{|l|}{ Family history of $\mathbf{R b}$} & $\mathrm{P}=0.83$ \\
\hline Yes & 11 & $\begin{array}{c}5.5 \% \\
(2.3-8.7) \\
\end{array}$ & 188 & \\
\hline Sporadic & 208 & $\begin{array}{c}5.2 \% \\
(4.5-5.9)\end{array}$ & 3808 & \\
\hline \multicolumn{4}{|l|}{ Bilaterality } & $P<0.001$ \\
\hline Unilateral & 126 & $\begin{array}{c}4.2 \% \\
(3.5-4.9)\end{array}$ & 2884 & \\
\hline Bilateral & 97 & $7.2 \%$ & 1244 & \\
\hline
\end{tabular}




\begin{tabular}{|c|c|c|c|c|c|}
\hline & & $(5.8-8.6)$ & & & \\
\hline \multicolumn{5}{|c|}{ Extraocular $\mathrm{Rb}$ at presentation } & $P=0.045$ \\
\hline Yes & 36 & $\begin{array}{c}3.9 \% \\
(2.6-5.1\end{array}$ & \multicolumn{2}{|c|}{890} & \\
\hline No & 187 & $\begin{array}{c}5.5 \% \\
(4.8-6.3)\end{array}$ & \multicolumn{2}{|c|}{3189} & \\
\hline \multicolumn{5}{|c|}{ Age at presentation: } & $\mathrm{P}=0.71$ \\
\hline & $\%$ & $95 \% \mathrm{Cl}$ & $\%$ & $95 \% \mathrm{Cl}$ & \\
\hline mean in months & 25.7 & $(22.8-28.5)$ & 27.0 & $(26.3-27.7)$ & \\
\hline
\end{tabular}

This article is protected by copyright. All rights reserved. 
Table 2. Travel across borders: 223 patients from 73 countries who were diagnosed with $\mathbf{R b}$ outside their country of residence.

\begin{tabular}{|c|c|c|c|}
\hline Country & $\begin{array}{l}\text { National } \\
\text { income level }\end{array}$ & $\begin{array}{l}\mathrm{N}=\text { patients that travelled } \\
\text { across borders } \\
\text { (total no. from country, \%) }\end{array}$ & $\begin{array}{l}\mathbf{N}=\mathbf{R b} \\
\text { centers in } \\
\text { country }\end{array}$ \\
\hline \multicolumn{4}{|l|}{ Africa } \\
\hline Algeria & $\begin{array}{l}\text { Upper- } \\
\text { middle }\end{array}$ & $3(13,23.1)$ & 1 \\
\hline Angola & $\begin{array}{l}\text { Lower- } \\
\text { middle }\end{array}$ & $1(17,5.9)$ & None \\
\hline Burkina Faso & Low & $2(29,6.9)$ & 1 \\
\hline Burundi & Low & $14(26,53.8)$ & 1 \\
\hline Cote d'ivoire & $\begin{array}{l}\text { Lower- } \\
\text { middle }\end{array}$ & $5(32,15.6)$ & 1 \\
\hline Democratic Republic of Congo & Low & $5(39,12.8)$ & 3 \\
\hline Egypt & $\begin{array}{l}\text { Lower- } \\
\text { middle }\end{array}$ & $1(129,0.8)$ & 3 \\
\hline Gambia & Low & $2(2,100)$ & None \\
\hline Guinea & Low & $1(1,100)$ & None \\
\hline Guinea-Bissau & Low & $1(1,100)$ & None \\
\hline Liberia & Low & $1(1,100)$ & None \\
\hline Libya & $\begin{array}{l}\text { Upper- } \\
\text { middle }\end{array}$ & $8(11,72.7)$ & 1 \\
\hline Mali & Low & $2(27,7.4)$ & 1 \\
\hline Morocco & $\begin{array}{l}\text { Lower- } \\
\text { middle }\end{array}$ & $3(29,10.3)$ & 3 \\
\hline Mozambique & Low & $1(14,7.1)$ & 2 \\
\hline Nigeria & $\begin{array}{l}\text { Lower- } \\
\text { middle }\end{array}$ & $2(130,1.5)$ & 10 \\
\hline Republic of the Congo & $\begin{array}{l}\text { Lower- } \\
\text { middle }\end{array}$ & $1(1,100)$ & None \\
\hline Rwanda & Low & $1(14,7.1)$ & 1 \\
\hline Sénégal & Low & $1(27,3.7)$ & 1 \\
\hline Sierra Leone & Low & $1(1,100)$ & None \\
\hline Somalia & Low & $1(1,100)$ & None \\
\hline South Africa & $\begin{array}{l}\text { Upper- } \\
\text { middle }\end{array}$ & $1(59,1.7)$ & 7 \\
\hline South Sudan & Low & $5(5,100)$ & None \\
\hline Sudan & $\begin{array}{l}\text { Lower- } \\
\text { middle }\end{array}$ & $5(13,38.5)$ & 1 \\
\hline \multicolumn{4}{|l|}{ Asia } \\
\hline Afghanistan & Low & $13(27,48.1)$ & 3 \\
\hline
\end{tabular}




\begin{tabular}{|c|c|c|c|}
\hline Azerbaijan & $\begin{array}{l}\text { Upper- } \\
\text { middle }\end{array}$ & $3(5,60.0)$ & 1 \\
\hline Bangladesh & $\begin{array}{l}\text { Lower- } \\
\text { middle }\end{array}$ & $13(161,8.1)$ & 3 \\
\hline Bhutan & $\begin{array}{l}\text { Lower- } \\
\text { middle }\end{array}$ & $1(1,100)$ & None \\
\hline Cambodia & $\begin{array}{l}\text { Lower- } \\
\text { middle }\end{array}$ & $1(22,4.5)$ & 1 \\
\hline India & $\begin{array}{l}\text { Lower- } \\
\text { middle }\end{array}$ & $1(558,0.2)$ & 18 \\
\hline Indonesia & $\begin{array}{l}\text { Lower- } \\
\text { middle }\end{array}$ & $3(159,1.9)$ & 9 \\
\hline Iraq & $\begin{array}{l}\text { Upper- } \\
\text { middle }\end{array}$ & $17(64,10.9)$ & 7 \\
\hline Kazakhstan & $\begin{array}{l}\text { Upper- } \\
\text { middle }\end{array}$ & $5(30,16.7)$ & 1 \\
\hline Kuwait & High & $2(2,100)$ & None \\
\hline Kyrgyzstan & $\begin{array}{l}\text { Lower- } \\
\text { middle }\end{array}$ & $4(9,44.4)$ & 1 \\
\hline Malaysia & $\begin{array}{l}\text { Upper- } \\
\text { middle }\end{array}$ & $1(21,4.8)$ & 1 \\
\hline Nepal & Low & $3(22,13.6)$ & 1 \\
\hline Oman & High & $1(1,100)$ & None \\
\hline Pakistan & $\begin{array}{l}\text { Lower- } \\
\text { middle }\end{array}$ & $1(184,0.5)$ & 6 \\
\hline Saudi Arabia & High & $4(5,80.0)$ & 1 \\
\hline State of Palestine & $\begin{array}{l}\text { Lower- } \\
\text { middle }\end{array}$ & $6(6,100)$ & None \\
\hline Syria & $\begin{array}{l}\text { Lower- } \\
\text { middle }\end{array}$ & $9(9,100)$ & None \\
\hline Tajikistan & $\begin{array}{l}\text { Lower- } \\
\text { middle }\end{array}$ & $1(1,100)$ & None \\
\hline Turkmenistan & $\begin{array}{l}\text { Upper- } \\
\text { middle }\end{array}$ & $2(2,100)$ & None \\
\hline United Arab Emirates & High & $1(1,100)$ & None \\
\hline Vietnam & $\begin{array}{l}\text { Lower- } \\
\text { middle }\end{array}$ & $2(108,1.9)$ & 2 \\
\hline Yemen & $\begin{array}{l}\text { Lower- } \\
\text { middle }\end{array}$ & $5(23,21.7)$ & 1 \\
\hline \multicolumn{4}{|l|}{ Europe } \\
\hline Albania & $\begin{array}{l}\text { Upper- } \\
\text { middle }\end{array}$ & $2(4,50.0)$ & 1 \\
\hline Andorra & High & $1(1,100)$ & None \\
\hline
\end{tabular}




\begin{tabular}{|c|c|c|c|}
\hline Armenia & $\begin{array}{l}\text { Lower- } \\
\text { middle }\end{array}$ & $2(3,66.7)$ & 1 \\
\hline Austria & High & $2(9,22.2)$ & 1 \\
\hline Bosnia and Herzegovina & $\begin{array}{l}\text { Upper- } \\
\text { middle }\end{array}$ & $3(3,100)$ & None \\
\hline Bulgaria & $\begin{array}{l}\text { Upper- } \\
\text { middle }\end{array}$ & $5(11,45.5)$ & 1 \\
\hline France & High & $1(49,2.0)$ & 1 \\
\hline Georgia & $\begin{array}{l}\text { Lower- } \\
\text { middle }\end{array}$ & $1(2,50.0)$ & 1 \\
\hline Greece & High & $4(4,100)$ & None \\
\hline Italy & High & $2(31,6.5)$ & 3 \\
\hline Kosovo & $\begin{array}{l}\text { Lower- } \\
\text { middle }\end{array}$ & $2(2,100)$ & None \\
\hline Lithuania & High & $1(2,50.0)$ & 1 \\
\hline Malta & High & $1(1,100)$ & None \\
\hline Moldova & $\begin{array}{l}\text { Lower- } \\
\text { middle }\end{array}$ & $3(3,100)$ & None \\
\hline Netherlands & High & $1(16,6.3)$ & 1 \\
\hline Norway & High & $5(9,55.6)$ & 1 \\
\hline Romania & $\begin{array}{l}\text { Upper- } \\
\text { middle }\end{array}$ & $4(8,50.0)$ & 1 \\
\hline Russia & $\begin{array}{l}\text { Upper- } \\
\text { middle }\end{array}$ & $3(84,3.6)$ & 3 \\
\hline Serbia & $\begin{array}{l}\text { Upper- } \\
\text { middle }\end{array}$ & $2(9,22.2)$ & 2 \\
\hline Ukraine & $\begin{array}{l}\text { Lower- } \\
\text { middle }\end{array}$ & $5(34,14.7)$ & 2 \\
\hline \multicolumn{4}{|l|}{ LAC } \\
\hline Antigua and Barbuda & High & $2(2,100)$ & None \\
\hline Jamaica & $\begin{array}{l}\text { Upper- } \\
\text { middle }\end{array}$ & $1(3,33.3)$ & 1 \\
\hline Mexico & $\begin{array}{l}\text { Upper- } \\
\text { middle }\end{array}$ & $1(32,3.1)$ & 2 \\
\hline Paraguay & $\begin{array}{l}\text { Upper- } \\
\text { middle }\end{array}$ & $1(10,10.0)$ & 3 \\
\hline Peru & $\begin{array}{l}\text { Upper- } \\
\text { middle }\end{array}$ & $1(74,1.4)$ & 5 \\
\hline Puerto Rico & High & $1(1,100)$ & None \\
\hline
\end{tabular}


Table 3. Multiple logistic regression analysis showing independently significant predictors predictors of international travel ( $n=4250 ; 53$ children from countries with no centre (since they would inevitably have travelled), and those with incomplete data for these 4 risk factors were excluded from this analysis

\begin{tabular}{|l|l|l|l|l|}
\hline & Predicting factor & Significance & Odd ratio & $\begin{array}{l}\mathbf{9 5 \%} \text { Cl for odds } \\
\text { ratio }\end{array}$ \\
\hline Patient related & Intraocular $\mathrm{Rb}$ & 0.015 & 0.572 & $0.365-0.895$ \\
\cline { 2 - 5 } & Bilateral $\mathrm{Rb}$ & $<0.0005$ & 0.549 & $0.400-0.753$ \\
\hline Country related & $\begin{array}{l}\text { Small population } \\
\text { size }\end{array}$ & $<0.0005$ & 0.180 & $0.115-0.281$ \\
\cline { 2 - 5 } & Low income status & 0.001 & 0.501 & $0.338-0.742$ \\
\hline
\end{tabular}


$298 \mathrm{Rb}$ centers from 134 countries contacted

$20 \mathrm{Rb}$ centers did not join in

$278 \mathrm{Rb}$ centers from 130 countries joined in the study and reported on 4,395 new $\mathrm{Rb}$ patients from 153

countries
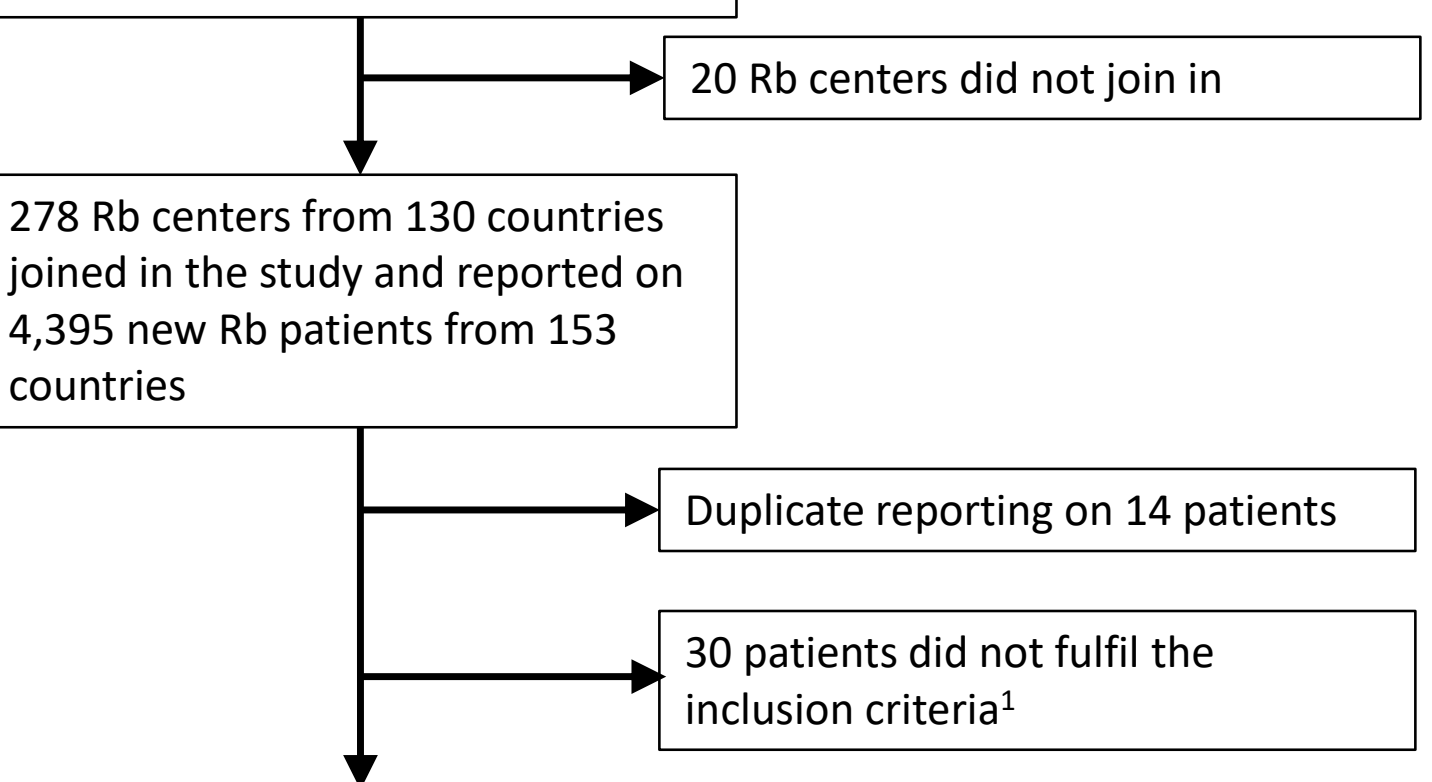

Study sample: 4,351 patients from

153 countries

223 patients from 73 countries

travelled abroad for $\mathrm{Rb}$ treatment

(sub-group \#2)

No data on travel distance for 634

patients

4,128 patients primarily treated in

their country of residence

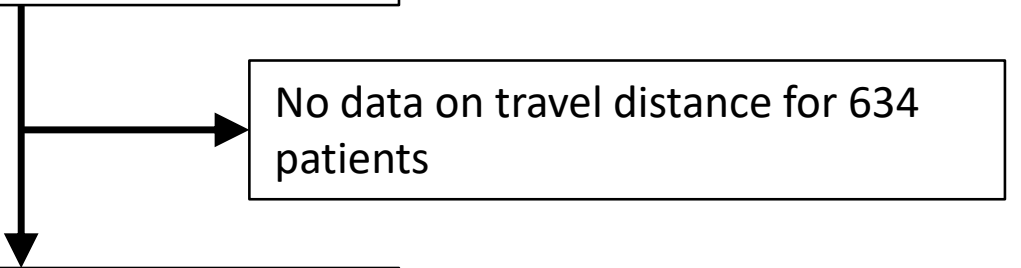

3,494 patients from 111 countries

(sub-group \#1) 


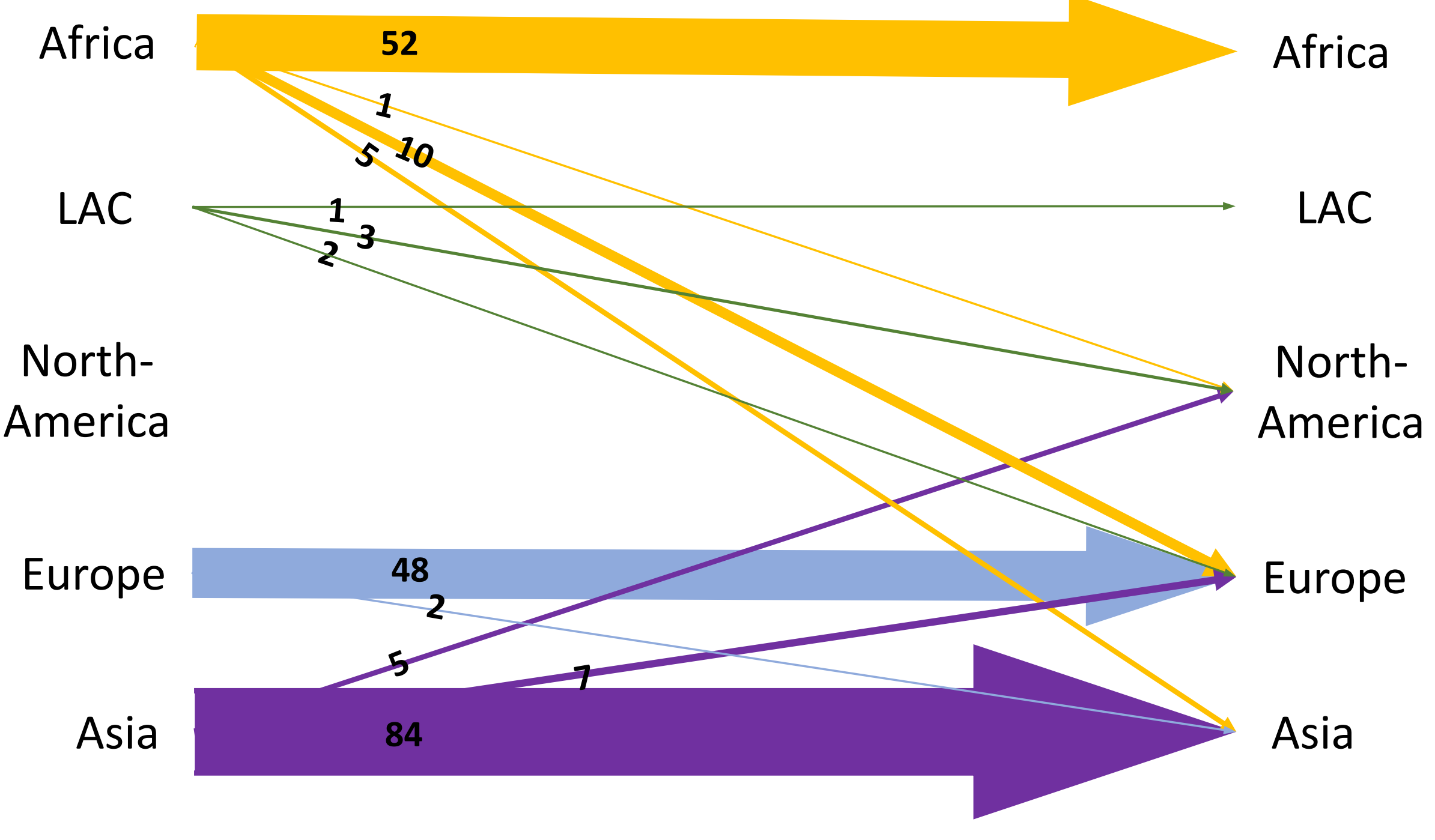




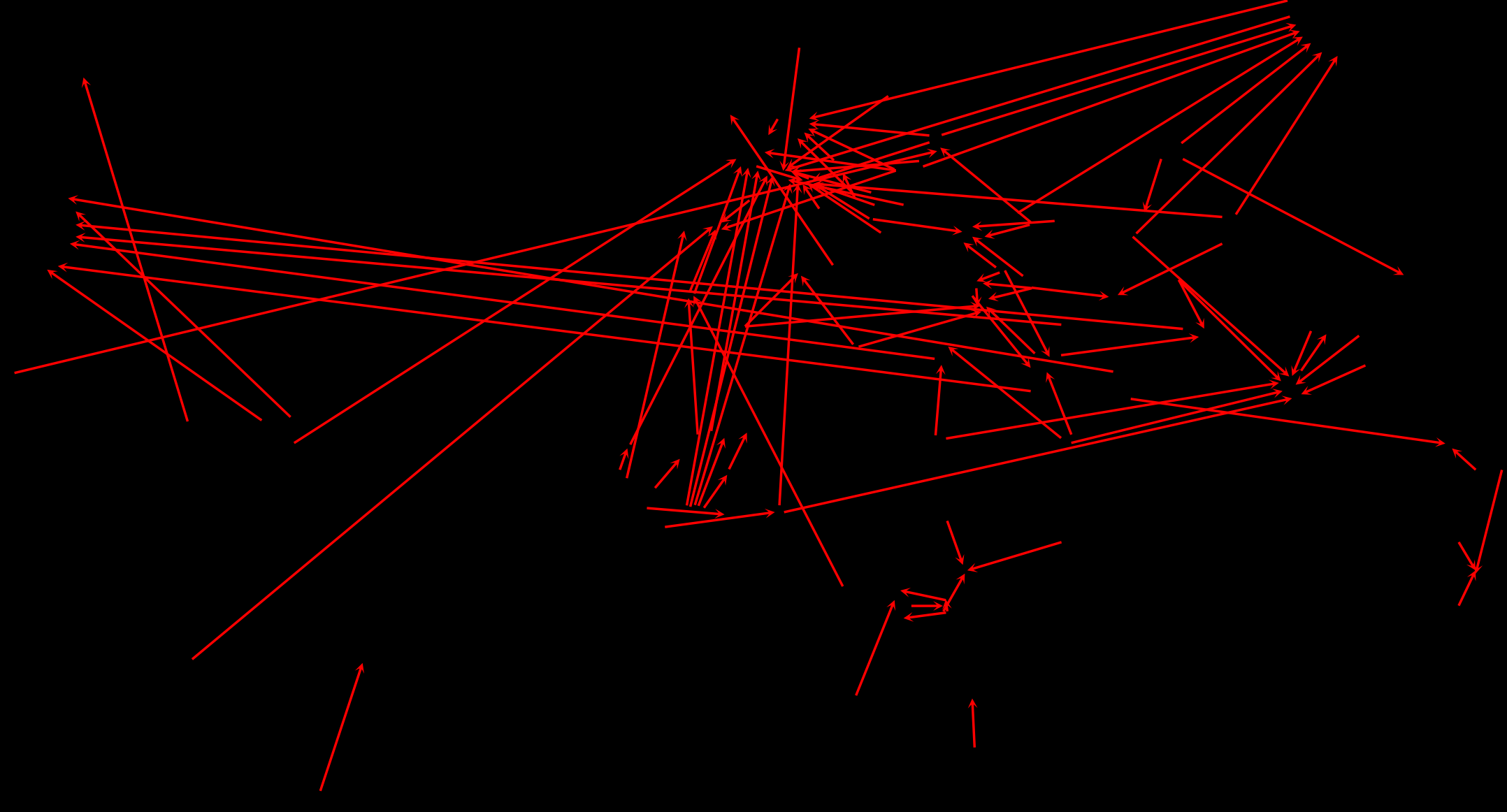



